\title{
Investment opportunities, free cash flow and market reaction to international joint ventures
}

\author{
Sheng-Syan Chen ${ }^{\text {a }}$, Kim Wai Ho ${ }^{b}$, Cheng-few Lee ${ }^{\mathrm{c}, *}$, \\ Gillian H.H. Yeo ${ }^{\mathrm{b}}$ \\ a Department of Finance, College of Management, Yuan Ze University, Taoyuan, Taiwan, ROC \\ b Division of Banking and Finance, Nanyang Business School, Nanyang Technological University, \\ Nanyang Avenue, 639798 Singapore, Singapore \\ ${ }^{\mathrm{c}}$ Department of Finance, School of Business, Rutgers University, New Brunswick, NJ 08903, USA
}

Received 15 March 1998; accepted 13 July 1999

\begin{abstract}
This paper examines the role of investment opportunities and free cash flow in explaining the source of the wealth effect of international joint ventures. We document that firms with promising investment opportunities have significantly positive response to announcements of international joint venture investments, whereas firms with poor investment opportunities have unfavorable response to such announcements. In contrast, we find that free cash flow does not explain the cross-sectional differences in abnormal returns associated with the announcements of international joint ventures. Thus, our results show support for the investment opportunities hypothesis but no support for the free cash flow hypothesis. These findings hold even after controlling for other potential explanatory variables. (c) 2000 Elsevier Science B.V. All rights reserved.
\end{abstract}

JEL classification: G14; G31

Keywords: International joint ventures; Investment opportunities; Free cash flow

\footnotetext{
${ }^{*}$ Corresponding author. Tel.: +908-445-3907; fax: +908-445-5927. Present address: Faculty of Management, Rutgers University, Rockafeller Road, Piscataway, NJ 08854-8054, USA.

E-mail address: lee@everest.rutgers.edu (C.-f. Lee).
} 


\section{Introduction}

Previous studies on the wealth effect of international joint ventures have shown mixed results. Lummer and McConnell (1990), Crutchley et al. (1991), and Chen et al. (1991) find that domestic participant firms experience significantly positive abnormal returns at announcements of international joint ventures. ${ }^{1}$ These studies show that size of investment, type and relative size of partners, and strength of home currency have significant explanatory power. ${ }^{2}$ In contrast, Finnerty et al. (1986) find little evidence of significant valuation effects associated with the announcements of international joint ventures, while Lee and Wyatt (1990) and Chung et al. (1993) document an overall negative market reaction to such announcement. ${ }^{3}$

Lee and Wyatt (1990) argue that the overall wealth loss associated with international joint ventures may be explained by Jensen (1986) free cash flow theory, which states that managers endowed with free cash flow will invest in wasteful investments rather than pay it out to shareholders. International joint ventures may be one such use of this free cash flow. The potential agency costs of international joint venture investments are therefore higher for high-freecash-flow firms. On the other hand, international joint venture investments by low-free-cash-flow firms increase the chance the firm will seek new external financing. New external financing provides monitoring, and the firm's willingness to undergo such monitoring may be a favorable signal (Szewczyk et al., 1996). Therefore, the free cash flow theory predicts that the market response to an international joint venture announcement would be inversely related to the firm's level of free cash flow. However, Lee and Wyatt (1990) did not provide evidence supporting their free cash flow argument. An investigation into the role of free cash flow in explaining the wealth effect of international joint ventures is important in view of the mixed support for Jensen's theory with respect to other types of corporate investments. The free cash flow theory has power in explaining the variation in bidder returns for domestic tender offers

\footnotetext{
${ }^{1}$ McConnell and Nantell (1985) show that announcements of domestic joint ventures are also associated with significantly positive abnormal returns.

${ }^{2}$ Lummer and McConnell (1990) find a positive relationship between the wealth gain and the amount of investment made by domestic participant firms, whereas Chen et al. (1991) find a negative relationship. Lummer and McConnell also document that international joint ventures with foreign firms create larger value increases than those with foreign governments. Crutchley et al. (1991) show that US shareholders earn larger abnormal returns when their firms are smaller than the Japanese joint venture partners. They also show that shareholder gains are larger when the home currency is relatively strong.

${ }^{3}$ Lee and Wyatt (1990) show that only those international joint ventures with firms from lesserdeveloped countries have nonnegative announcement effects while Chung et al. (1993) find that the market tends to respond unfavorably to announcements of international joint ventures regardless of the economic status of the partner's home country.
} 
(Lang et al., 1991) and international acquisitions (Doukas, 1995), but lacks power in explaining abnormal returns associated with announcements of R\&D expenditures (Vogt, 1994; Szewczyk et al., 1996), product strategies and capital expenditures (Chen and Ho, 1997).

The role of investment opportunities in explaining the cross-sectional differences in market reaction to announcements of international joint ventures have also not been examined in the literature. Recent research shows that the availability or lack of investment opportunities, as proxied by Tobin's $q$, is an important consideration in assessing the wealth effect of corporate investment decisions such as domestic tender offers (Lang et al., 1991), international acquisitions (Doukas, 1995), R\&D expenditures (Chan et al., 1990; Zantout and Tsetsekos, 1994; Szewczyk et al., 1996), product strategies (Chen and Ho, 1997) and capital expenditures (Blose and Shieh, 1997; Chen and Ho, 1997; Chung et al., 1998). Specifically, they show that corporate investments by firms with good investment opportunities are generally worthwhile while those by firms with poor investment opportunities may be wasteful. ${ }^{4}$

The purpose of this paper is to examine the importance of investment opportunities and free cash flow in explaining the wealth effect of international joint venture investments. We investigate a sample of Singapore listed firms that announced international joint venture decisions during the period 19791993. Singapore is a small and open economy and hence, international joint venture is a very important mode of business expansions, especially in recent years when the government of Singapore actively promotes Singapore as a gateway for European, US and other firms to expand into Asia. This study also provides important international evidence on the wealth effect of international joint ventures as existing studies focus mainly on US data. By way of comparison, our sample firms have, on average, better investment opportunities than US bidder firms, but poorer investment opportunities than US firms that announce R\&D investments. The average free cash flow measure for our sample firms is close to that for the US bidder firms.

Our results show that announcements of international joint ventures by Singapore firms are, on average, associated with positive abnormal returns. These results are similar to those found in the US by Lummer and McConnell (1990), Crutchley et al. (1991), and Chen et al. (1991). We find support for the investment opportunities hypothesis that investments in international joint ventures by firms with good investment opportunities are generally worthwhile whereas such investments by firms with poor investment opportunities are not. Our results hold after controlling for other variables that could affect the abnormal returns. This evidence, together with the results on other types of

\footnotetext{
${ }^{4}$ Lang and Ofek (1995) also find a positive and significant relationship between the announcement effects and the firms' Tobin's $q$ for a sample of US investments in Eastern Europe.
} 
corporate investment decisions, suggests that the availability or lack of investment opportunities is an important consideration in assessing the wealth effect of different types of corporate investments.

We find that free cash flow does not explain the cross-sectional differences in abnormal returns associated with the announcements of international joint ventures. This evidence is similar to that for other types of strategic investments such as R\&D investments, product strategies and capital expenditures. ${ }^{5}$ These findings thus suggest that, in general, the free cash flow hypothesis may apply to intercorporate acquisitions, but not to strategic investments. This is consistent with the explanation by Chen and Ho (1997) that managers who plan to misuse the firm's free cash flow on negative NPV projects may be more likely to do so on acquisitions than on strategic investments. Another possible reason is that our sample firms and those firms that invest in $R \& D$, product strategies and capital expenditures have, on average, better investment opportunities than the bidder firms, and hence, the agency problems of free cash flow may not be as severe.

The remainder of the paper is organized as follows. Section 2 describes the sample selection and description. Section 3 presents the results. The final section concludes.

\section{Sample selection and description}

Our sample selection process starts with the identification of announcements of international joint ventures between Singapore listed firms and either foreign companies, foreign governments, or both, during the period from January 1979 to December 1993. The initial announcements are collected from the Daily Financial News, which are compilations of corporate announcements received by the Stock Exchange of Singapore on the day before its publication. Our definition of announcement date (day 0) is the date of the Daily Financial News in which the company's initial announcement appears. This corresponds to the announcement date in the United States where day 0 refers to the date when the international joint ventures are reported in the Wall Street Journal.

We include initial international joint venture announcements if data on the firms are available from the Stock Exchange of Singapore and their financial statements. Our sample comprises 174 announcements by 85 different Singapore firms. Table 1 reports a distribution of the sample by time profile and industry classification. There is some clustering of announcements during

\footnotetext{
${ }^{5} \mathrm{R} \& \mathrm{D}$ investments, join ventures, product strategies and capital expenditures fall into the definition of corporate strategic investments by Woolridge (1988).
} 
Table 1

Sample distribution of international joint venture announcements by time profile and industry classification $^{\mathrm{a}}$

\begin{tabular}{|c|c|c|c|c|c|c|}
\hline \multirow[t]{2}{*}{ Year } & \multicolumn{4}{|l|}{ Industry } & \multirow{2}{*}{$\begin{array}{l}\text { Total number of } \\
\text { announcements } \\
\text { in each year }\end{array}$} & \multirow{2}{*}{$\begin{array}{l}\text { Percent of } \\
\text { total sample } \\
(\%)\end{array}$} \\
\hline & $\begin{array}{l}\text { Industrial \& } \\
\text { commercial }\end{array}$ & Finance & Hotels & Properties & & \\
\hline 1979 & 2 & 0 & 0 & 0 & 2 & 1.2 \\
\hline 1980 & 1 & 0 & 0 & 0 & 1 & 0.6 \\
\hline 1981 & 5 & 0 & 0 & 0 & 5 & 2.9 \\
\hline 1982 & 1 & 0 & 0 & 1 & 2 & 1.2 \\
\hline 1983 & 2 & 0 & 3 & 2 & 7 & 4.0 \\
\hline 1984 & 6 & 0 & 0 & 1 & 7 & 4.0 \\
\hline 1985 & 5 & 0 & 0 & 1 & 6 & 3.4 \\
\hline 1986 & 7 & 0 & 0 & 1 & 8 & 4.6 \\
\hline 1987 & 6 & 0 & 0 & 0 & 6 & 3.4 \\
\hline 1988 & 6 & 1 & 0 & 1 & 8 & 4.6 \\
\hline 1989 & 6 & 0 & 1 & 1 & 8 & 4.6 \\
\hline 1990 & 10 & 1 & 1 & 3 & 15 & 8.6 \\
\hline 1991 & 9 & 1 & 0 & 1 & 11 & 6.3 \\
\hline 1992 & 15 & 1 & 1 & 2 & 19 & 10.9 \\
\hline 1993 & 57 & 1 & 0 & 11 & 69 & 39.7 \\
\hline Total & 138 & 5 & 6 & 25 & 174 & 100.0 \\
\hline
\end{tabular}

${ }^{a}$ This table summarizes the distribution of international joint venture announcements by Singapore firms from 1979 to 1993 . There are 174 announcements by 85 different Singapore firms. The industries are based on the industry classification by the Singapore Stock Exchange. The sample is obtained from the Daily Financial News issued by the Stock Exchange of Singapore.

1990-1993. However, on a daily basis, the announcements were noncontemporaneous. The industry classification is based on that used by the Singapore Stock Exchange, but interpretation of this industry classification is limited because of the broadly defined industry groups.

Table 2 reports the information on the explanatory variables used in the next section of the paper. Data are obtained from the financial statements of the firms, the Daily Financial News, and the Stock Exchange of Singapore. Tobin's $q$ has been widely used to distinguish firms with good investment opportunities from those with poor investment opportunities (Lang et al., 1989, 1991; Howe et al., 1992; Doukas, 1995; Szewczyk et al., 1996; and others). The theoretical Tobin's $q$ is defined as the ratio of the market value of a firm to the replacement costs of its assets. Because of data availability, we estimate $q$ as the ratio of the market value of the firm's assets to the book value of the firm's assets, where the market value of assets equals the book value of assets minus the book value of common equity plus the market value of common equity. This simple measure of $q$ for investment opportunities (the "pseudo $q$ ") has 
Table 2

Sample characteristics ${ }^{\mathrm{a}}$

\begin{tabular}{llccc}
\hline Variables & $N$ & Mean & Median & $\begin{array}{c}\text { Standard } \\
\text { deviation }\end{array}$ \\
\hline Pseudo $q$ & & & 1.1 & 1.7 \\
Market-adjusted change on pseudo $q$ & 174 & 0.08 & 0.02 & 0.43 \\
Cash flow (\%) & 174 & 5.1 & 3.5 & 6.4 \\
Firm size (US millions) & 174 & 834 & 178 & 2717 \\
Dollar investment (US millions) & 124 & 5.5 & 2.6 & 11.7 \\
Dollar investment/TA (\%) & 124 & 4.4 & 1.2 & 7.6 \\
Debt ratio (\%) & 174 & 45.7 & 45.2 & 17.8 \\
Dividend yield (\%) & 174 & 1.7 & 1.5 & 1.3 \\
Managerial ownership (\%) & 157 & 21.8 & 3.8 & 26.9 \\
\hline
\end{tabular}

${ }^{a}$ The sample consists of 174 international joint venture announcements by Singapore firms from 1979 to 1993. Data are obtained from the financial statements of the firms, the Daily Financial News, and the Stock Exchange of Singapore. Pseudo $q$ is estimated as the average ratio of the market value of the firm's assets to the book value of the firm's assets for the three fiscal years before the announcement, where the market value of assets is estimated as the book value of assets minus the book value of common equity plus the market value of common equity. Market-adjusted change on pseudo $q$ is measured by the average of the annual changes on the announcing firm's pseudo $q$ relative to the market over the three fiscal years before the announcement, where the annual change on pseudo $q$ relative to the market is the announcing firm's annual pseudo $q$ change minus the average annual pseudo $q$ change of all listed firms (excluding the announcing firm). The cash flow variable is defined as operating income before depreciation minus interest expense, taxes, preferred dividends, and common dividends, all divided by total assets, for the year preceding the announcement. Firm size is the announcing firm's market value of assets for the year preceding the announcement. Dollar investment/TA is the amount of investment made by the announcing firm divided by its book value of total assets for the year preceding the announcement. Debt ratio is 1 minus the ratio of the book value of equity to the book value of total assets for the year preceding the announcement. Dividend yield is the announcing firm's dividend to price per share for the year preceding the announcement. Managerial ownership is the stock ownership by directors for the year preceding the announcement. The numbers of observations for dollar investment, dollar investment/TA, and managerial ownership are smaller because of data availability.

been widely used in previous studies. ${ }^{6}$ Our pseudo $q$ variable is the average pseudo $q$ for the three fiscal years prior to the announcement. ${ }^{7}$ The mean $q$ of our sample firms is 1.4 which is close to the mean $q$ of 1.52 for US R\&D firms (Szewczyk et al., 1996), 1.35 for US firms that announced capital budget increases (Blose and Shieh, 1997), and 1.33 and 1.30 for Singapore firms that announced product strategies and capital expenditures, respectively (Chen and

\footnotetext{
${ }^{6}$ See, for example, Denis (1994), Perfect and Wiles (1994), Barclay and Smith (1995a,b), Agrawal and Knoeber (1996), Kang and Stulz (1996), Chen and Ho (1997), and Holderness et al. (1999). Chung and Pruitt (1994) show that at least $96.6 \%$ of the variability of Tobin's $q$ (based on Lindenberg and Ross, 1981) is explained by this simple measure of $q$.

${ }^{7}$ This follows the approach used in Lang et al. (1991), Szewczyk et al. (1996), and Chen and Ho (1997). A three-year average gives a better estimate of a firm's true $q$ (Lang et al., 1989).
} 
Ho, 1997). The mean $q$ s of firms that announced these strategic investments are substantially higher than the mean $q$ of 0.86 for US bidder firms (Lang et al., 1989).

We also look at the change on pseudo $q$ relative to the market as an alternative measure of the firm's future investment opportunities. ${ }^{8} \mathrm{~A}$ high average $q$ may merely show that good investment decisions have been made in the past, and it need not imply anything about the future investment opportunities. A market-adjusted change on the announcing firm's $q$ may provide a better measure of future opportunities. A firm with a rising $q$ is perceived as being more likely to have growth opportunities than one that has a declining $q$. We estimate the market-adjusted change on pseudo $q$ as the average of the annual changes on the announcing firm's $q$ relative to the market over the three fiscal years before the announcement, where the annual change on $q$ relative to the market is the announcing firm's annual $q$ change minus the average annual $q$ change of all listed firms (excluding the announcing firm). ${ }^{9}$ The mean market-adjusted change on $q$ for our sample firms is 0.08 and its median is 0.02. ${ }^{10}$ These results, together with the results obtained when the average pseudo $q$ is used as a proxy for investment opportunities, suggest that our sample firms on average have good investment opportunities.

Following Lehn and Poulsen (1989), Lang et al. (1991), Howe et al. (1992), Doukas (1995), and Szewczyk et al. (1996), we define cash flow as operating income before depreciation minus interest expense, taxes, preferred dividends, and common dividends for the fiscal year preceding the announcement, divided by the book value of total assets. The mean cash flow ratio of our sample firms is 5.1\%. The mean cash flow ratio in Szewczyk et al. (1996) sample of US R\&D firms is $8.67 \%$ while the mean cash flow ratio in Lang et al. (1991) sample of US bidder firms is $6.1 \%$. Thus, the average cash flow ratio for our sample firms is closer to that for the US bidder firms.

In addition to $q$ and cash flow, we also use data on firm size, size of investment, debt ratio, dividend yield, and managerial ownership for our sample firms. Firm size is the announcing firm's market value of assets for the year preceding the announcement. The size of investment (dollar investment/TA) is the amount of investment made by the announcing firm divided by its book value of total assets for the year preceding the announcement. Debt ratio is 1 minus the ratio of the book value of equity to the book value of total assets for the year preceding the announcement. Dividend yield is the announcing firm's

\footnotetext{
${ }^{8} \mathrm{We}$ appreciate one anonymous referee for this helpful suggestion.

${ }^{9}$ The motivation for using the average of the annual changes is that the $q$ estimates may be noisy (Lang et al., 1989) so that taking an average change in $q$ may lead to a better estimate of a firm's true future investment opportunities.

${ }^{10}$ The $t$-statistics and the Wilcoxon $z$-statistics indicate that both the mean and median changes are significantly different from zero at the $5 \%$ level using two-tailed tests.
} 
dividend to price per share for the year preceding the announcement. Managerial ownership is the stock ownership by directors for the year preceding the announcement. The numbers of observations for dollar investment, dollar investment/TA, and managerial ownership are smaller because of data availability.

\section{Empirical results}

\subsection{Overall sample}

We employ standard event-study methods to examine stock price responses to announcements of international joint ventures. Data are obtained from the Stock Exchange of Singapore. The two-day (days -1 to 0 ) abnormal return for each security is measured by the deviation of the security's realized return over the two-day period from an expected return generated by the market model. Market model parameters are estimated over a period from 200 to 60 days before the initial announcements. The value-weighted Stock Exchange of Singapore All-Share Index is used to measure market return. The results of the event study are reported in Table 3 .

The average two-day announcement-period abnormal return of our sample firms is $0.96 \%$, significant at the $1 \%$ level. ${ }^{11}$ Furthermore, the median abnormal return is $0.56 \%$ (also significant at the $1 \%$ level) and $60 \%$ of the sample announcement effects are positive, indicating that the average two-day abnormal return is not driven by outlier observations. No significant abnormal returns are observed preceding and following the announcement period. Thus, shareholders of our sample firms experience significant wealth gains from international joint ventures, similar to those found in the US by Lummer and McConnell (1990), Crutchley et al. (1991), and Chen et al. (1991).

\subsection{Analysis of subsamples}

Following Lang et al. (1991), Howe et al. (1992), Doukas (1995), and Szewczyk et al. (1996), we divide our sample firms according to whether the announcing firms have a pseudo $q$ greater or less than one. High- $q$ firms (i.e. firms with good investment opportunities) are those with pseudo $q$ above one while low- $q$ firms (i.e. firms with poor investment opportunities) are those with

\footnotetext{
${ }^{11}$ In three cases, two different Singapore sample firms are involved in the same deal. We find that all of them have pseudo $q$ greater than 1 , have positive market-adjusted changes on pseudo $q$, and have positive announcement-period abnormal returns.
} 
Table 3

Cumulative abnormal returns ${ }^{\mathrm{a}}$

\begin{tabular}{llllll}
\hline $\begin{array}{l}\text { Period relative } \\
\text { to the } \\
\text { announcement }\end{array}$ & $\begin{array}{l}\text { Mean } \\
\text { abnormal } \\
\text { return (\%) }\end{array}$ & -Statistics & $\begin{array}{l}\text { Median } \\
\text { abnormal } \\
\text { return }(\%)\end{array}$ & $\begin{array}{l}P \text {-Value for } \\
\text { the Wilcoxon } \\
z \text {-statistics }\end{array}$ & $\begin{array}{l}\text { Proportion } \\
\text { of positive } \\
\text { abnormal } \\
\text { returns }(\%)\end{array}$ \\
\hline$[-30,-2]$ & 1.35 & 1.07 & 0.56 & 0.13 & 52 \\
{$[-20,-2]$} & 0.67 & 0.96 & 0.34 & 0.33 & 52 \\
{$[-10,-2]$} & 0.65 & 1.32 & 0.16 & 0.24 & 51 \\
{$[-1,0]$} & 0.96 & $3.39^{* * *}$ & 0.56 & $<0.01$ & 60 \\
{$[1,10]$} & 0.87 & 1.47 & 0.01 & 0.62 & 50 \\
{$[1,20]$} & 0.91 & 1.07 & 0.09 & 0.70 & 51 \\
{$[1,30]$} & 1.04 & 0.96 & -0.25 & 0.79 & 49 \\
\hline
\end{tabular}

${ }^{\mathrm{a}}$ The sample consists of 174 international joint venture announcements by Singapore firms from 1979 to 1993 . Cumulative abnormal returns are estimated using the standard market model procedure with parameters estimated for the period 200 days to 60 days before the announcement. Day 0 in event time is the date of the announcement's report on the Daily Financial News issued by the Stock Exchange of Singapore.

*** $1 \%$ Significance level.

pseudo $q$ below one. Panel A, Table 4, shows that high- $q$ firms have significantly positive average (median) two-day announcement-period abnormal return of $1.64 \%(0.82 \%)$. In contrast, the average and median abnormal returns for the low- $q$ firms are negative although they are not statistically significant. The mean difference between the abnormal returns for high- and low$q$ firms is statistically significant at the $1 \%$ level. This result is robust to possible deviations from nonnormality, since it also holds for the nonparametric Kruskal-Wallis test statistics. As also shown in Panel A, the results are similar if firms with good investment opportunities are defined as those with positive market-adjusted changes on pseudo $q$ while firms with poor investment opportunities are those with negative market-adjusted changes on pseudo $q$. These findings are consistent with the investment opportunities hypothesis: Investments in international joint ventures by firms with good growth opportunities are worthwhile while those by firms with poor growth opportunities are not. ${ }^{12}$

Panel A, Table 4, also shows comparisons based on cash flow. High-cashflow (low-cash-flow) firms have cash flow above (below) the median for the

\footnotetext{
${ }^{12}$ We also examine the market reactions of the sample firms that announce more than one deal and are in different categories of pseudo $q$ (i.e. $q>1$ or $q<1$ ). We find that for these sample firms the mean and median announcement-period abnormal returns of high- $q$ category are significantly higher than those of low- $q$ category. The results are similar if market-adjusted changes on pseudo $q$ (i.e. positive or negative changes) are used. Our results suggest that the investment opportunities hypothesis holds for the same firm when different deals are announced.
} 


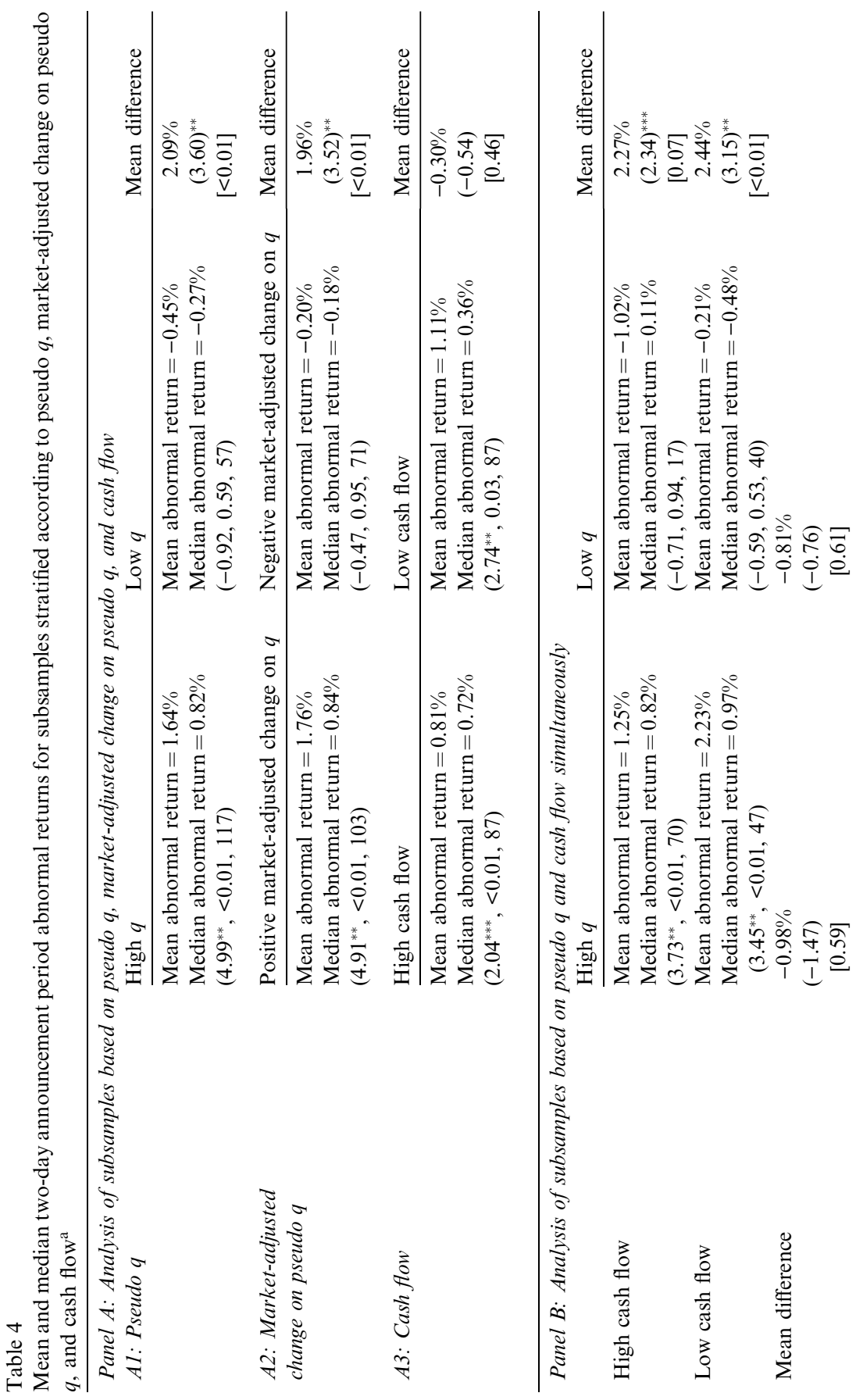




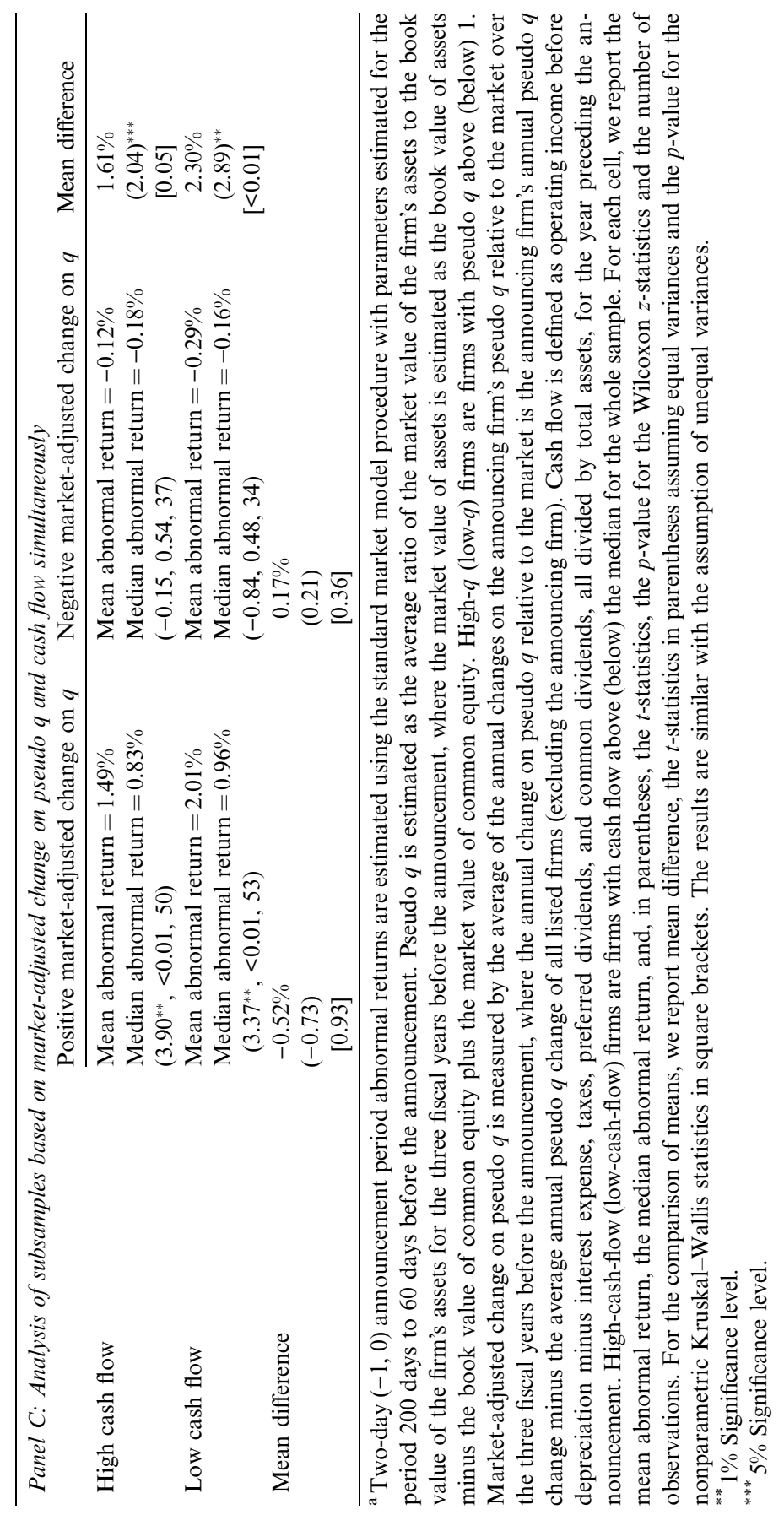




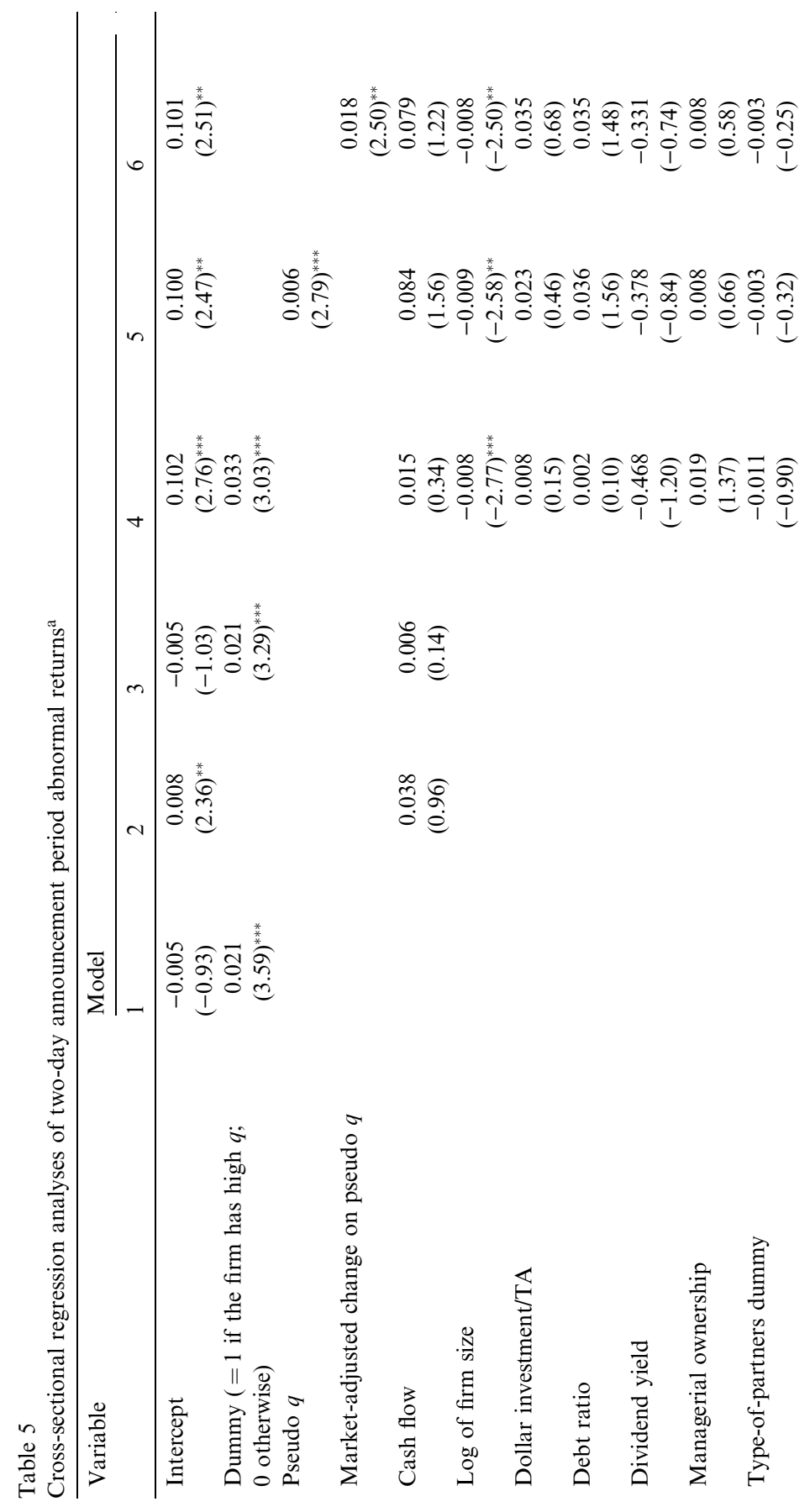




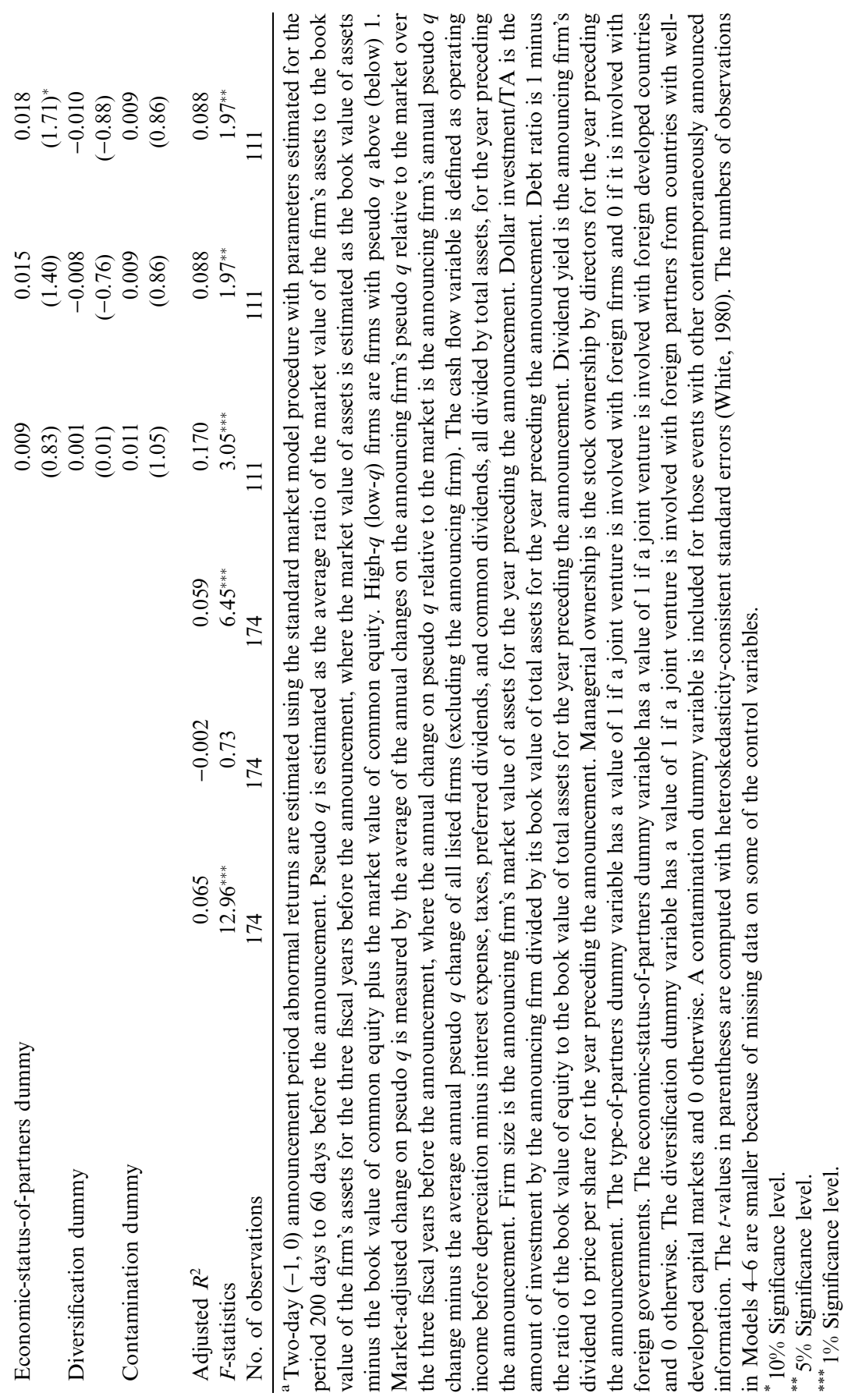


whole sample. ${ }^{13}$ We find no significant difference in abnormal returns between high- and low-cash-flow firms. ${ }^{14}$

We also present a $2 \times 2$ table (Panel B, Table 4) for our sample firms stratified according to pseudo $q$ and cash flow simultaneously. The free cash flow hypothesis predicts that high- $q$ /low-cash-flow (low- $q /$ high-cash-flow) firms have the lowest (highest) potential agency costs associated with investments in international joint ventures, and hence, should have the highest and positive (lowest and negative) announcement-period abnormal returns. Our results show that the subsample of high- $q$ /low-cash-flow firms has a significantly positive average (median) abnormal return of $2.23 \%(0.97 \%)$, the highest among the four subsamples. However, there is no statistically significant difference in average abnormal returns between high- $q$ /low-cash-flow and high- $q$ l high-cash-flow firms and between low- $q$ /high-cash-flow and low- $q$ /low-cashflow firms. These results do not support the free cash flow hypothesis.

Results in Panel B, Table 4, provide support for the investment opportunities hypothesis. For each of the subsamples of high-cash-flow and low-cashflow firms, high- $q$ firms have significantly higher average (median) abnormal returns than do low- $q$ firms.

We also present the results for our sample firms stratified according to the market-adjusted change on pseudo $q$ and cash flow simultaneously, as shown in Panel C, Table 4. The results are similar. In our sample of international joint ventures, the investment opportunities hypothesis is supported whereas the free cash flow hypothesis is not.

\subsection{Cross-sectional regression analysis}

Table 5 presents cross-sectional analysis of the announcement-period abnormal returns for our sample. The $t$-values are computed with heteroskedasticity-consistent standard errors (White, 1980). ${ }^{15}$ Following Lang et al.

\footnotetext{
${ }^{13}$ This classification follows that of Lang et al. (1991), Howe et al. (1992), Doukas (1995), and Szewczyk et al. (1996).

${ }^{14}$ Similar to footnote 12, we also compare the stock market reactions of the sample firms that announce more than one deal and are in different categories of cash flow (i.e. high or low cash flow). We find that for these sample firms the mean and median announcement-period abnormal returns are not significantly different between high-cash-flow category and low-cash-flow category. Our results suggest that the free cash flow hypothesis does not hold for the same firm when different deals are announced.

${ }^{15}$ The results are similar if we reestimate the regressions using weighted least squares, with the weights equal to the reciprocal of the standard deviation of the market model residual, an approach used in Lang et al. (1991).
} 
(1991) and Doukas (1995), we use a dummy that takes a value of one for firms with a pseudo $q$ that exceeds one and zero otherwise. ${ }^{16}$

The significance of investment opportunities and free cash flow are tested separately in models 1 and 2, respectively, and jointly in model 3 . We find that the investment opportunities hypothesis is supported but the free cash flow hypothesis is not. The coefficient for the dummy pseudo $q$ variable is positive and statistically significant while that for the cash flow variable is not. ${ }^{17}$ The results are consistent with those of Table 4.

Model 4 regresses abnormal returns against the dummy pseudo $q$ variable, cash flow, and several other potential factors. ${ }^{18}$ If, as many researchers suggest (e.g. see Hertzel and Smith, 1993; Kang and Stulz, 1996), information asymmetry is likely to be more severe for small firms, we expect market reaction to be negatively related to firm size ceteris paribus. Following Lummer and McConnell (1990) and Chen et al. (1991), we include the size of investment in the model. We measure size of investment as dollar investment relative to book value of total assets of the firm. ${ }^{19}$ The firm's debt ratio and dividend yield are included as alternative measures of free cash flow (Jensen, 1986) and investment opportunities (Smith and Watts, 1992), respectively. Managerial ownership is included to control for ownership structure effects (Jensen and Meckling, 1976). ${ }^{20}$ Firms with tightly-held shareholdings may have lesser agency problems of free cash flow. A dummy variable for the type of partners is used to control for any differential wealth effect between international joint ventures with foreign firms and those with foreign governments (Lummer and McConnell, 1990). This dummy variable has a value of 1 if a joint venture is with foreign firms and 0 if it is with foreign governments. ${ }^{21}$ A dummy variable for the economic status of partners is also included in the model because Lee and Wyatt (1990) find that the stock valuation effects of international joint ventures are related to the economic status of the partner's home country. This

\footnotetext{
${ }^{16}$ The motivation is that a sufficient condition for the availability of good investment opportunities is a $q$ that exceeds one. Furthermore, the relationship between abnormal returns and $q$ may be nonlinear. Lang et al. (1989) and Chung et al. (1998) provide similar reasons for their preference for the dichotomous variable for investment opportunities.

${ }^{17}$ Following Lang et al. (1991), we also include another variable in model 3: cash flow if the firm has low $q$ and 0 otherwise. This is designed to test another prediction of the free cash flow hypothesis that the abnormal return of low- $q$ firms in comparison with high- $q$ firms decreases with the cash flow of low- $q$ firms. The results do not support this prediction.

${ }^{18}$ The numbers of observations in models 4 to 6 are smaller because of missing data on some of the control variables.

${ }^{19}$ The results are similar if we divide dollar investment by the firm's market value of assets for the year preceding the announcement.

${ }^{20}$ There is no publicly available data on institutional holdings in Singapore.

${ }^{21}$ Of the 174 international joint venture announcements, 29 had foreign governments as partners.
} 
dummy variable has a value of 1 if a joint venture is with foreign partners from developed countries and 0 otherwise. ${ }^{22}$ The economic status of countries is based on the IMF economic status classification (see World Economic Outlook, 1992). To control for the impact of diversification benefits, we include a dummy variable that has a value of 1 if a joint venture is with foreign partners from countries with well-developed capital markets and 0 otherwise. ${ }^{23} \mathrm{~A}$ country is considered to have a well-developed capital market if it has stock data listed in International Financial Statistics (1992). If diversification benefits exist, joint ventures with foreign partners from countries with undeveloped capital markets should display more pronounced effects on stock prices (Lummer and McConnell, 1990). Finally, a 'contamination' dummy is used to control for 'contaminated' events where there are simultaneous announcements. ${ }^{24}$

Results in model 4 are consistent with those in Table 4 . After controlling for other potentially influential factors, the investment opportunities hypothesis still holds while there is no support for the free cash flow hypothesis.

To test the robustness of our results, we also substitute the continuous pseudo $q$ variable for the dummy pseudo $q$ variable in the complete regression model 4 . The results are reported in model 5 . In model 6 , the continuous pseudo $q$ variable is replaced by the market-adjusted change on pseudo $q$ variable. Both models 5 and 6 show similar results as in model 4: The investment opportunities hypothesis holds while the free cash flow hypothesis does not. ${ }^{25}$ The only control variable that is consistently significant across the complete regression models 4 to 6 is the firm size variable. The smaller the firm, the more favorable is the market response.

\section{Conclusion}

This paper examines the role of investment opportunities and free cash flow in explaining the wealth effect of international joint ventures. We show that firms with favorable investment opportunities have significantly positive response to announcements of international joint venture investments whereas firms with poor investment opportunities have negative response to such an-

\footnotetext{
2248 observations had foreign partners from developed countries.

2353 observations had foreign partners from countries with well-developed capital markets.

2424 observations had contemporaneous announcements.

${ }^{25}$ We have also included the following variables in models 4 to 6: (1) industry dummies; (2) ownership squared (to allow for possible nonlinear relationship); and (3) liquid assets (defined as cash and short-term securities divided by the book value of the firm's total assets two years before the announcement, as in Lang et al. (1991). None of these variables is significant. The results for the other variables in the regression models are essentially unchanged.
} 
nouncements. Our results are consistent with the investment opportunities hypothesis and hold even after controlling for other factors which could affect the market's response to the announcements. Our findings, together with those on intercorporate acquisitions (Lang et al., 1991; Doukas, 1995), R\&D investments (Szewczyk et al., 1996), capital expenditures (Blose and Shieh, 1997; Chen and Ho, 1997; Chung et al., 1998) and product strategies (Chen and Ho, 1997), suggest that the availability or lack of investment opportunities is an important consideration in assessing the wealth effect of different types of corporate investments.

In contrast, we find that free cash flow does not explain the cross-sectional differences in abnormal returns associated with the announcements of international joint ventures. Our results do not support the free cash flow hypothesis. This evidence is similar to that for R\&D expenditures (Vogt, 1994; Szewczyk et al., 1996), product strategies and capital expenditures (Chen and Ho, 1997), but different from that for intercorporate acquisitions (Lang et al., 1991; Doukas, 1995), which generally supports the free cash flow theory. These findings suggest that the free cash flow hypothesis may apply to intercorporate acquisitions, but not to strategic investments.

\section{Acknowledgements}

The authors wish to thank Min-Teh Yu, Zaher Zantout, and especially an anonymous referee for helpful comments and suggestions. The paper has also benefited from comments of the seminar participants at the 1997 FMA meetings and the National Central University, Taiwan. Any remaining errors are the authors'.

\section{References}

Agrawal, A., Knoeber, C.R., 1996. Firm performance and mechanisms to control agency problems between managers and shareholders. Journal of Financial and Quantitative Analysis 31, 377397.

Barclay, M.J., Smith Jr, C.W., 1995a. The maturity structure of corporate debt. Journal of Finance 50, 609-631.

Barclay, M.J., Smith Jr, C.W., 1995b. The priority structure of corporate liabilities. Journal of Finance 50, 899-917.

Blose, L.E., Shieh, J.C.P., 1997. Tobin's $q$-ratio and market reaction to capital investment announcements. Financial Review 32, 449-476.

Chan, S.H., Martin, J., Kensinger, J., 1990. Corporate R\&D expenditures and share value. Journal of Financial Economics 26, 255-276.

Chen, H., Hu, M.Y., Shieh, J.C.P., 1991. The wealth effect of international joint ventures: The case of US investment in China. Financial Management 20, 31-41. 
Chen, S.S., Ho, K.W., 1997. Market response to product-strategy and capital-expenditure announcements in Singapore: Investment opportunities and free cash flow. Financial Management 26, 82-88.

Chung, I.Y., Koford, K.J., Lee, I., 1993. Stock market views of corporate multinationalism: Some evidence from announcements of international joint ventures. Quarterly Review of Economics and Finance 33, 275-293.

Chung, K.H., Pruitt, S.W., 1994. Simple approximation of Tobin's $q$. Financial Management 23, 70-74.

Chung, K.H., Wright, P., Charoenwong, C., 1998. Investment opportunities and market reaction to capital expenditure decisions. Journal of Banking and Finance 22, 41-60.

Crutchley, C.E., Guo, E., Hansen, R.S., 1991. Stockholder benefits from Japanese-US joint ventures. Financial Management 20, 22-30.

Denis, D.J., 1994. Investment opportunities and the market reaction to equity offerings. Journal of Financial and Quantitative Analysis 29, 159-177.

Doukas, J., 1995. Overinvestment, Tobin's $q$ and gains from foreign acquisitions. Journal of Banking and Finance 19, 1285-1303.

Finnerty, J.E., Owers, J.E., Rogers, R.C., 1986. The valuation impact of joint ventures. Management International Review 26, 14-26.

Hertzel, M., Smith, R.L., 1993. Market discounts and shareholder gains for placing equity privately. Journal of Finance 48, 459-485.

Holderness, C.G., Kroszner, R.S., Sheehan, D.P., 1999. Were the good old days that good? Changes in managerial stock ownership since the great depression. Journal of Finance 54, 435469.

Howe, K.M., He, J., Kao, G.W., 1992. One-time cash flow announcements and free cash-flow theory: Share repurchases and special dividends. Journal of Finance 47, 1963-1975.

International Financial Statistics, 1992. Washington, DC, International Monetary Fund.

Jensen, M.C., 1986. Agency costs of free cash flow, corporate finance, and takeovers. American Economic Review 76, 323-329.

Jensen, M.C., Meckling, W.H., 1976. Theory of the firm: Managerial behavior, agency costs and ownership structure. Journal of Financial Economics 3, 305-360.

Kang, J.K., Stulz, R.M., 1996. How different is Japanese corporate finance? An investigation of the information content of new security issues. Review of Financial Studies 9, 109-139.

Lang, L.H.P., Ofek, E., 1995. Why do firms invest in Eastern Europe. European Financial Management 1, 147-171.

Lang, L.H.P., Stulz, R.M., Walkling, R.A., 1989. Managerial performance Tobin's $q$, and the gains from successful tender offers. Journal of Financial Economics 24, 137-154.

Lang, L.H.P., Stulz, R.M., Walkling, R.A., 1991. A test of the free cash flow hypothesis: The case of bidder returns. Journal of Financial Economics 29, 315-335.

Lee, I., Wyatt, S.B., 1990. The effects of international joint ventures on shareholder wealth. Financial Review 25, 641-649.

Lehn, K., Poulsen, A., 1989. Free cash flow and stockholder gains in going private transactions. Journal of Finance 44, 771-787.

Lindenberg, E., Ross, S., 1981. Tobin's $q$ ratio and industrial organization. Journal of Business 54, $1-32$.

Lummer, S.L., McConnell, J.J., 1990. Stock valuation effects of international joint ventures. In: Rhee, S.G., Chang, R.P. (Eds.), Pacific-Basin Capital Markets Research. Elsevier Science Publishers, New York, pp. 531-546.

McConnell, J.J., Nantell, T.J., 1985. Corporate combinations and common stock returns: The case of joint ventures. Journal of Finance 40, 519-536.

Perfect, S.B., Wiles, K.W., 1994. Alternative constructions of Tobin's $q$ : An empirical comparison. Journal of Empirical Finance 1, 313-341. 
Smith Jr, C.W., Watts, R.L., 1992. The investment opportunity set and corporate financing, dividend, and compensation policies. Journal of Financial Economics 32, 263-292.

Szewczyk, S.H., Tsetsekos, G.P., Zantout, Z., 1996. The valuation of corporate R\&D expenditures: Evidence from investment opportunities and free cash flow. Financial Management 25, 105110.

Vogt, S., 1994. The cash flow/investment relationship: Evidence from US manufacturing firms. Financial Management 23, 3-20.

White, H., 1980. A heteroskedasticity-consistent covariance matrix estimator and a direct test for heteroskedasticity. Econometrica 48, 817-838.

Woolridge, J.R, 1988. Competitive decline and corporate restructuring: Is a myopic stock market to blame. Journal of Applied Corporate Finance 1, 26-36.

World Economic Outlook, 1992. International Monetary Fund, Washington, DC.

Zantout, Z., Tsetsekos, G., 1994. The wealth effects of announcements of R\&D expenditure increases. Journal of Financial Research 17, 205-216. 